\title{
Transition zones analysis using empirical capillary pressure model from well logs and 3D seismic data on 'Stephs' field, onshore, Niger Delta, Nigeria
}

\author{
O. Abiola ${ }^{1}$ (D) F. O. Obasuyi ${ }^{1}$
}

Received: 10 April 2019 / Accepted: 24 November 2019 / Published online: 6 December 2019

(c) The Author(s) 2019

\begin{abstract}
Capillary pressure is an important characteristic that indicates the zones of interaction between two-phase fluids or fluid and rock occurring in the subsurface. The analysis of transition zones (TZs) using Goda (Sam) et al.'s empirical capillary pressure from well logs and 3D seismic data in 'Stephs' field, Niger Delta, was carried out to remove the effect of mobile water above the oil-water contact in reservoirs in the absence of core data/information. Two reservoirs (RES B and C) were utilized for this study with net thicknesses (NTG) ranging from 194.14 to $209.08 \mathrm{~m}$. Petrophysical parameters computed from well logs indicate that the reservoirs' effective porosity ranges from 10 to $30 \%$ and the permeability ranges from 100 to $>1000 \mathrm{mD}$, which are important characteristics of good hydrocarbon bearing zone. Checkshot data were used to tie the well to the seismic section. Faults and horizons were mapped on the seismic section. Time structure maps were generated, and a velocity model was used to convert the time structure maps to its depth equivalent. A total of six faults were mapped, three of which are major growth faults (F1, F4 and F5) and cut across the study area. Reservoir properties were modelled using SIS and SGS. The capillary pressure log, curves and models generated were useful in identifying the impact of mobile water in the reservoir as they show the trend of saturating and interacting fluids. The volume of oil estimated from reservoirs $B$ and $C$ without taking TZ into consideration was $273 \times 10^{6}$ and $406 \times 10^{6} \mathrm{mmbbls}$, respectively, and was found to be higher than the volume of oil estimated from the two reservoirs while taking TZ into consideration which was $242 \times 10^{6}$ and $256 \times 10^{6} \mathrm{mmbbls}$, respectively. The results have indicated the presence of mobile water, which have further established that conventionally recoverable hydrocarbon (RHC) is usually overestimated; hence, TZ analysis has to be performed for enhancing RHC for cost-effective extraction and profit maximization.
\end{abstract}

Keywords Capillary pressure $\cdot$ Transition zone analysis $\cdot$ Reservoir properties $\cdot$ Recoverable hydrocarbon

\section{Introduction}

The oil transition zone is the zone occurring between the zone of $100 \%$ water saturation $\left(S_{\mathrm{w}}\right)$ and the zone of $100 \%$ hydrocarbon saturation $\left(S_{\mathrm{h}}\right)$ which consists of mobile water above the irreducible water saturation. At the meeting point of two fluids, capillary pressure is zero and $S_{\mathrm{w}}$ in reservoirs decreases with increasing height above the free water level (FWL). Two non-miscible fluids sharing the same porous space tend to occupy different positions depending on their

O. Abiola

oabiola@futa.edu.ng

1 Department of Applied Geophysics, Federal University of Technology, Akure, Nigeria density contrast (Glover 2000; Pascoal 2015). Vavra et al. (1992), Hartmann and Beaumont (1999), Larsen et al. (2000), Sarwaruddin et al. (2001), Kumar et al. (2002), Wiltgen et al. (2003), Johan and Svein (2005), Okoli and Ujanbi (2007), Jamiolahmady et al. (2007), Zhao et al. (2008), Renzo et al. (2010) and Goda (Sam) et al. (2011) have employed a different approach to analyse the oil transition zone and saturation height above free water level using semi-empirical relationship from Leverett (1941), Skelt and Harrison (1995), Christiansen (2001), Wu (2004), amongst others, with special core analysis (SCAL) under laboratory conditions. Hydrocarbon saturation in a reservoir can be overestimated when the effect of mobile water occurring in the transition zones within the reservoir is not accounted for while estimating reserves (Fig. 1a). The hydrocarbon-water transition zone is constrained upwards by the hydrocarbon 
Fig. 1 a Estimate of fluid distribution without taking transition zone into consideration. $\mathbf{b}$ Transition zone was considered while analysing fluid distribution. OWC is oil-water contact and $P_{\mathrm{c}}$ is capillary pressure

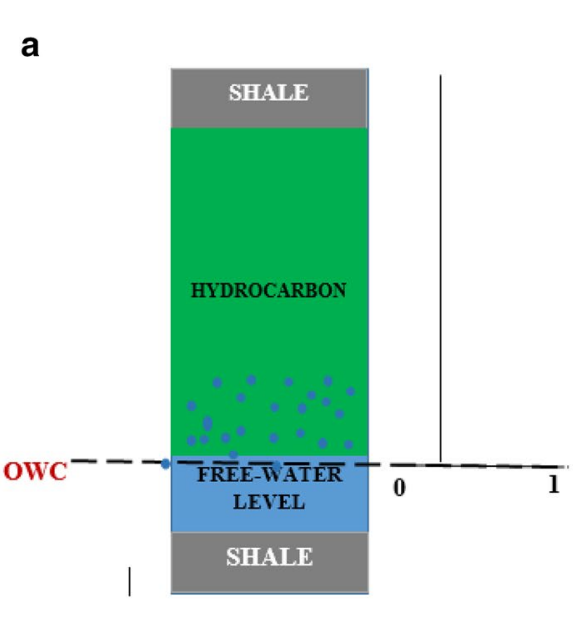

zone where the water saturation is close or equal to the irreducible water saturation (Fig. 1b). Capillary pressure is an important characteristic of rock that helps determine where hydrocarbons and water are located in the subsurface $(\mathrm{Wu}$ 2004). Capillary pressure curve is a plot of capillary pressure against water saturation which shows the trend of saturating and interacting fluids. It describes fluids interaction or fluid and matrix interaction with respect to the reservoir architecture. Each capillary pressure curve is specific to a facies, pore size distribution and fluid properties (Larsen et al. 2000; Glover 2000; Pascoal 2015). Larsen et al. in (2000) classified the reservoir transition zone into three: homogeneous (reservoir sand without thin layers of shale), layer dependent (thin shale layer occurring in reservoir sand) and heterogeneous transition zones (multiple thin shale layers occurring within reservoir sand). From capillary pressure, hydrocarbon/water contacts, rock matrix type and pore throat structure, heights of transition zones within the reservoir can be determined. In this study, a universal empirical model by Goda (Sam) et al. (2011) for obtaining the reservoir capillary pressure information of a field in the absence of core information was utilized and validated using well logs information from 'Stephs' field.

\section{Location and geology of the study area}

The study area (Fig. 2), 'Stephs' field, has a total of 672 inlines (6649-7321) and 424 crosslines (925-1349) and is located in the onshore part of the Niger Delta which lies within latitudes of $3^{\circ}$ and $5^{\circ} \mathrm{N}$ and longitudes of $5^{\circ}$ and $8^{\circ} \mathrm{E}$ and is made up of fresh water swamps and mangrove swamps with relief that increases towards the north. The sediments in the area are deposited in shallow marine environment. The Niger Delta is one of the world's largest tertiary delta systems and is situated on the West African continental margin at the apex of the Gulf of Guinea (Doust, and Omatsola 1990). The Niger Delta basin covers an area of $75,000 \mathrm{~km}^{2}$ (Sonibare et al. 2008). It was formed during the continental breakup in the Cretaceous era, with the delta developing from Palaeocene. The lithostratigraphic sequence of the Niger Delta is divided into three formations (Fig. 3). The Akata Formation (Palaeocene to recent), the base of the delta, consists of thick shale deposited under marine conditions. The overlying Agbada Formation (Eocene to Recent) consists of inter-bedded shale and sandstones and is overlain by the Benin Formation (latest Eocene to Recent), which is composed of coastal plain sands (Sonibare et al, 2008).

\section{Materials and methods}

The data sets used for the study include geophysical well logs in ASCII format (resistivity, neutron, density, gamma ray and sonic logs) from one well, 3-D seismic data in SEG-Y format and check shot data. The software used includes Petrel $2013^{\mathrm{TM}}$ and Microsoft Excel. Figure 4 is the workflow adopted for this work. Two hydrocarbon sands (RES B and C) were delineated from the well logs. The petrophysical parameters were computed conventionally and also computed by introducing macroscripts into the Petrel software. Checkshot data were used to tie the well to the seismic section. Faults and horizons were mapped on the seismic section. Time structure maps were generated, and a velocity model was used to convert the time structure map to its depth equivalent. Reservoir properties were modelled using sequential Gaussian indicator (SIS) and sequential Gaussian simulation (SGS). Capillary pressure was empirically derived using the Goda (Sam) et al.'s (2011) mathematical capillary equation which requires that the maximum, entry capillary pressure and petrophysical parameters be estimated or assumed. The maximum capillary pressure utilized in this study was taken to be 35 psi. 


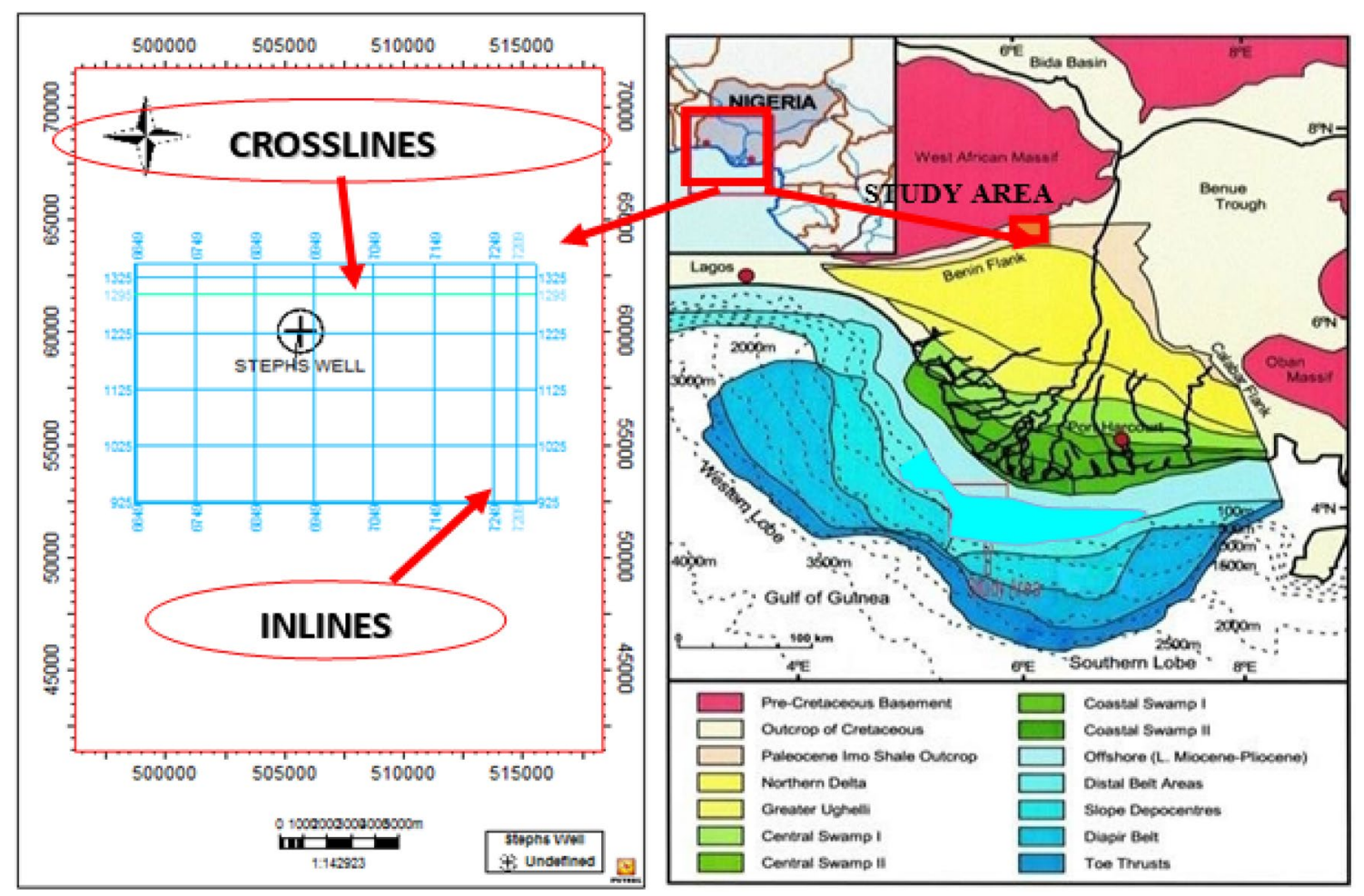

Fig. 2 Location and base map of the study area
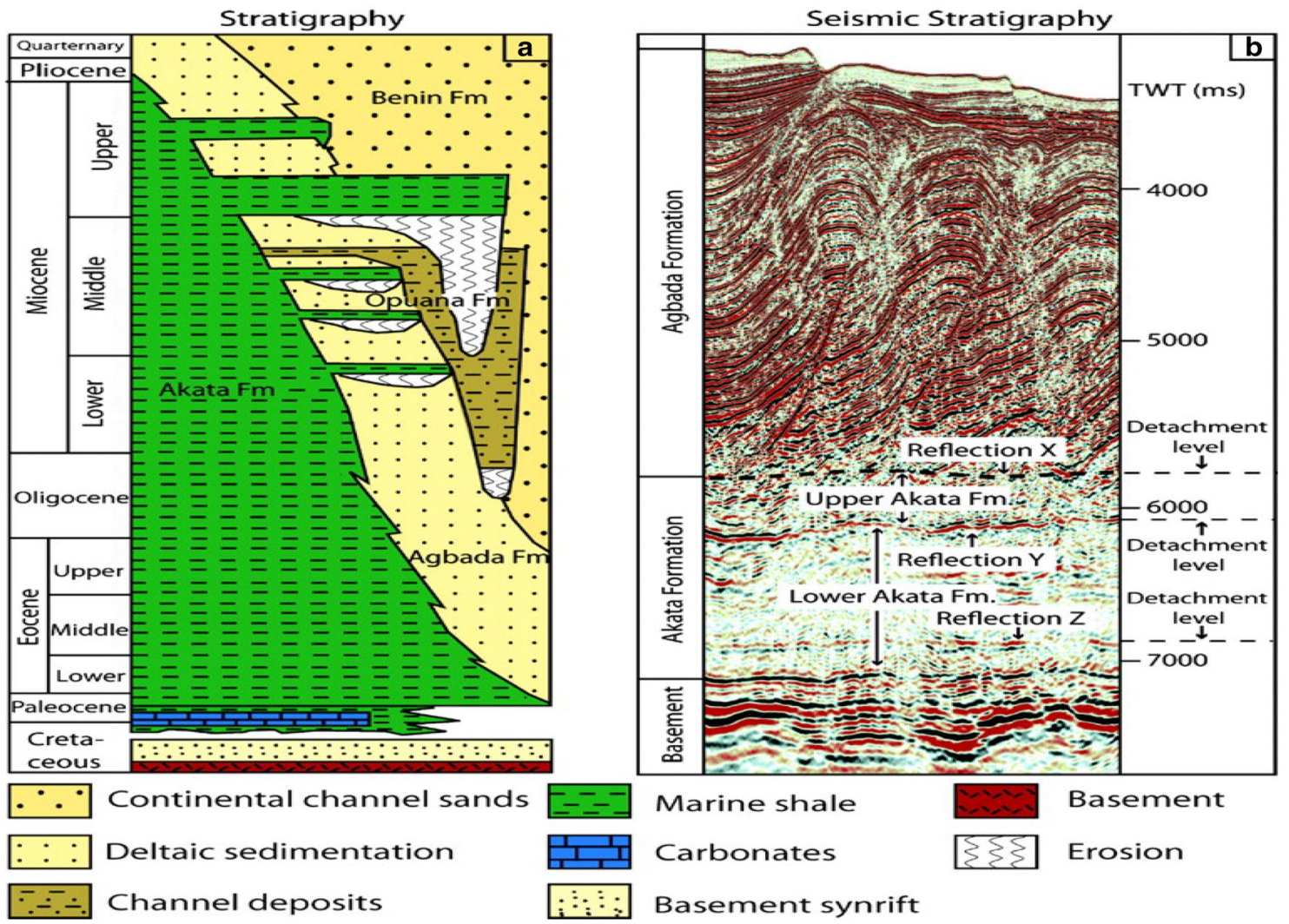

Fig. 3 Stratigraphy of the Niger Delta. (Doust and Omatsola 1990) 
Fig. 4 Workflow

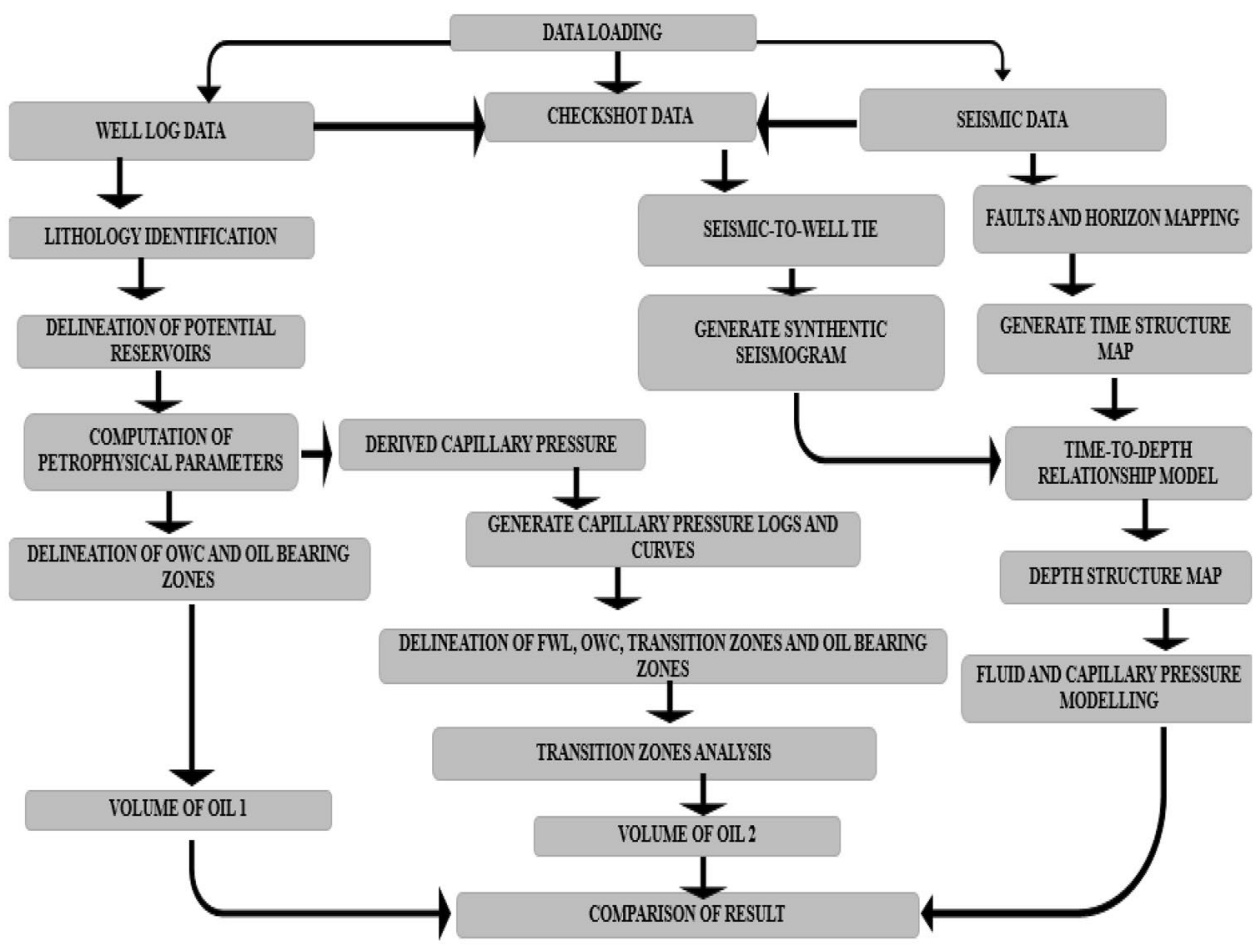

\section{Computation of petrophysical parameters}

Equations 1-7 were used to compute the petrophysical parameters, while Eqs. 8 and 9 were used to derive Goda (Sam) et al.'s (2011) empirical capillary pressure which incorporates some of the computed petrophysical parameters. The derived capillary pressure was used to generate capillary pressure logs, curves and models for the reservoir zones.

(a) Volume of shale (Larionov's 1969):

$I_{\mathrm{GR}}=\frac{\mathrm{GR}_{\log -\mathrm{GR}_{\min }}}{\mathrm{GR}_{\max }-\mathrm{GR}_{\min }}$

$\mathrm{VSH}=\left(0.083\left(2^{3.7 * I_{\mathrm{GR}}}-1\right)\right)$

The macroscript below was used to control the value range for gamma ray index $\left(\mathrm{I}_{\mathrm{GR}}\right)$ and volume of shale $\left(V_{\mathrm{SH}}\right)$ :

$I_{\mathrm{GR}}=\left(\left(\mathrm{GAMMA} \_\mathrm{RAY}-\mathrm{GR}_{\min }\right) /\left(\mathrm{GR}_{\max }-\mathrm{GR}_{\min }\right)\right)$

$V_{\mathrm{SH}}=0.083 *\left(\operatorname{Pow}\left(2,\left(3.7 *\left(I_{\mathrm{GR}}\right)\right)\right)-1.0\right)$

For better accuracy, the gamma ray index $\left(I_{\mathrm{GR}}\right)$ was estimated by considering each reservoir independently with respect to their gamma ray maximum $\left(\mathrm{GR}_{\max }\right)$ and gamma ray minimum $\left(\mathrm{GR}_{\min }\right)$ values.

(b) Porosity $(\Phi)$ :

Total porosity $(\Phi)$ is the ratio of pore volume per unit volume of a formation; it is the fraction of the total volume of a sample occupied by pores or voids, usually expressed as a percentage:

Mathematically, Porosity $(\phi)=\frac{\text { Pore volume }}{\text { Bulk Volume }} \times 100$.

Porosity is determined using density log as follows:

$\operatorname{PHID}(\emptyset)=\frac{\rho_{\mathrm{ma}}-\rho_{b}}{\rho_{\mathrm{ma}}-\rho_{\mathrm{fl}}}$

where $\rho_{b}$ is the measured density, $\rho_{\mathrm{ma}}$ is the density of the rock matrix (usually a constant of 2.65 for Niger Delta) and $\rho_{\mathrm{ff}}$ is the density of fluid (for water zone $1.1 \mathrm{gm} / \mathrm{cc}, 0.9$ for oil zones and 0.74 for gas zones).

$\operatorname{PHIE}\left(\emptyset_{\mathrm{eff}}\right)=\left(1-V_{\mathrm{sh}}\right) * \emptyset$

PHID is the total porosity and PHIDF is effective porosity of the fluid zones. The macroscript used to control the value range is 
PHIDF $=$ If $($ PHID $<=0.15,0.15$, If $($ PHID $>=0.40,0.40$, PHID $))$

(c) Permeability (K), Tixier (1949):

$K=\left(\frac{250 * \emptyset^{3}}{S_{\text {wirr }}}\right)^{2} \quad S_{\text {wirr }}=\sqrt{\frac{F}{2000}} \quad F=\frac{0.62}{\phi^{2.15}}$

The macroscript used to control the value range is

PERMEABILITY_F $=$ If (PERMEABILITY

$>=10000,10000$, PERMEABILITY)

(d) Water saturation, Archie's (1942):

$S w=\sqrt{\frac{R w}{\emptyset^{2} R t}}$

The macroscript used to control the value range is

$$
\begin{aligned}
\text { SW_F } & =\text { If }(\text { WATER_SAT }<=0,0, \text { If }(\text { WATER_SAT }> \\
& =1,1, \text { WATER_SAT }))
\end{aligned}
$$

(e) Hydrocarbon saturation computation:

$\mathrm{HC}=1-S_{\mathbf{w}}$

$\mathrm{HC}$ is the hydrocarbon saturation

(f) Empirical capillary pressure model:

This was estimated using the Goda (Sam) et al.'s (2011) empirical capillary pressure of equation to generate capillary pressure log, curves and models for each reservoir zone:

$P_{c}=\frac{P_{c_{\max }}\left[\frac{S_{\text {wirr }}}{S_{w}}\right]^{0.5}}{\left[1+\left[P_{c_{\max }}\left[S_{\text {wirr }}\right]^{0.5}-1\right]\left[\frac{1-\emptyset}{1-\emptyset S_{w}}\right] S_{w}^{*}\right]}$

where $S_{w}^{*} \frac{S_{w}-S_{\text {wirr }}}{1-S_{\text {wirr }}}$

where $S_{\mathrm{w}}^{*}$ is the normalized water saturation, $S_{\mathrm{wirr}}$ is the irreducible water saturation, $\varnothing$ is the effective porosity, $P_{\text {cmax }}$ is the maximum capillary pressure (35 psi), $\mathrm{S}_{\mathrm{w}}$ is the water saturation and $\varnothing_{\mathrm{Sw}}$ is the effective saturation. The range of values computed by coding the formulae above in Petrel ${ }^{\mathrm{TM}}$ was controlled with the script below.

GODA_(HUSSAM)_PC $=$ If $(\mathrm{PC}<=0,0$, If $(\mathrm{PC}>=35,35, \mathrm{PC}))$

\section{Capillary pressure and fluid modelling}

Fluid models were generated from the fluid logs using SGS. The Goda (Sam) et al.'s (2011) mathematical model was used to derive capillary pressure, and capillary pressure logs were generated. Point attributes and surfaces of the stratigraphic reservoir zones were generated and upscaled under the geometric modelling function on Petrel and the capillary pressure distribution for each zone generated. The sequential Gaussian simulation was used in modelling the empirical capillary pressure for reservoirs B and C, respectively.

\section{Volume calculation}

The hydrocarbon pore volume was calculated on Petrel (using Eq. 10). A case was created using the OWC, porosity and computed $\mathrm{S}_{\mathbf{w}}$. Then, the polygon edge boundary was used as fluid boundary to run a case model, the recovery factor was set to 1 and the volume estimate was achieved for each zone:

$\mathrm{HCPV}=\mathrm{A} * \emptyset *\left(1-S_{w)}\right) * h$

In estimating the volume of oil in place, two cases were considered. The first case was estimating the volume of oil in place without taking transition zone into consideration (volume of oil 1), and the second case was estimating the oil in place while taking transition zone into consideration (volume of oil 2).

\section{Results and discussion}

Two reservoirs $\mathrm{B}$ and $\mathrm{C}$ were delineated using the composite well logs (gamma ray, deep resistivity, neutron, density and sonic $\log$ ) made available for the well (Fig. 5). Table 1 shows the net and gross thickness for reservoirs B and C, respectively.

\section{Petrophysical parameters}

The computed petrophysical parameters (Table 2) show the reservoir units to have good reservoir quality. The petrophysical parameters were estimated using conventional (1D) approach and by incorporating Eqs. 1-7 as macroscript into Petrel $^{\mathrm{TM}}$ software. The reservoir unit is porous and permeable; as such, the reservoir unit can be said to be potential hydrocarbon bearing zones that can house and transmit economic quantity of hydrocarbon.

\section{Volume of shale}

The volume of shale estimated using the Larionov's (1969) equation shows the drilled region composed mainly of sand and shale. The reservoir zone of interest is found to be composed of sand up to 80-90\%. Sand/sandstone has the capability of being porous and permeable; as such, it can house hydrocarbon and transmit it in economic quantity. 
Fig. 5 Well section showing the reservoir units

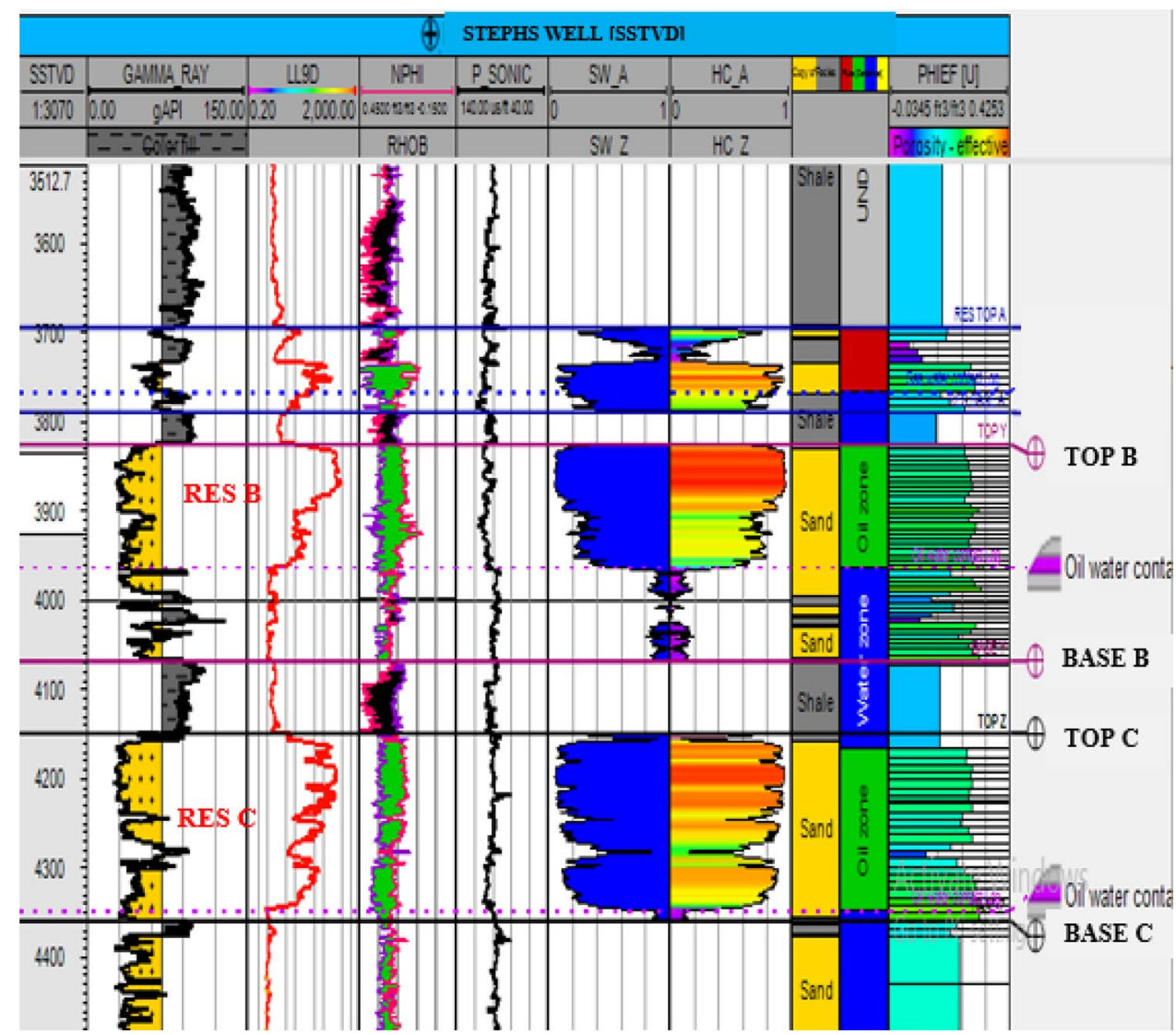

Table 1 Reservoir depth and parameter values used to estimate petrophysical parameters

\begin{tabular}{|c|c|c|c|c|c|c|c|c|}
\hline $\begin{array}{l}\text { Name of the } \\
\text { reservoir }\end{array}$ & Depth (m) top & Depth (m) base & $\begin{array}{l}\text { Gross } \\
\text { thickness } \\
\text { (m) }\end{array}$ & Net thickness (m) & $\begin{array}{l}\text { Net to gross } \\
\text { thickness } \\
\text { (ratio) }\end{array}$ & $\begin{array}{l}\text { Average net to } \\
\text { gross (ratio) }\end{array}$ & $\begin{array}{l}\text { Gamma ray } \\
\text { maximum }\end{array}$ & $\begin{array}{l}\text { Gamma } \\
\text { ray mini- } \\
\text { mum }\end{array}$ \\
\hline Res B & 3823.54 & 4066.83 & 243.29 & 209.08 & 0.86 & 0.91 & 129.84 & 25.76 \\
\hline $\operatorname{Res} C$ & 4142.81 & 4358.10 & 215.29 & 194.14 & 0.90 & 0.88 & 96.20 & 24.50 \\
\hline
\end{tabular}

Table 2 Petrophysical parameter values

\begin{tabular}{lllllllll}
\hline $\begin{array}{l}\text { Name of the } \\
\text { reservoir }\end{array}$ & Density & Total porosity & $\begin{array}{l}\text { Effective } \\
\text { porosity }\end{array}$ & $\begin{array}{l}\text { Permeability } \\
(\mathrm{mD})\end{array}$ & Volume of shale & $\begin{array}{l}\text { Net to gross } \\
\text { (ratio) }\end{array}$ & $\begin{array}{l}\text { Formation } \\
\text { volume factor }\end{array}$ & $\begin{array}{l}\text { Irreducible } \\
\text { water satura- } \\
\text { tion }\end{array}$ \\
\hline Res B & 2.17 & 0.27 & 0.26 & 4220 & 0.084 & 0.84 & 10.46 \\
Res C & 2.16 & 0.28 & 0.27 & 4333 & 0.0107 & 0.90 & 13.03 & 0.072 \\
\hline
\end{tabular}

\section{Effective porosity}

Effective porosity for reservoirs $\mathrm{B}$ and $\mathrm{C}$ is relatively high, as it falls in the range of $5-40 \%$. The proposed qualitative classes by Abiola et al. (2018) were modified and used as a guide for the classification of effective porosity (Table 3 ). The hydrocarbon region has effective porosity ranging from 15 to $30 \%$ and average porosity value as computed from the well $\log$ s to be 0.26 or $26 \%$ (Table 2). These reservoirs have very good porosity to house hydrocarbon. 
Table 3 Qualitative evaluation of effective porosity (Modified from Abiola et al. 2018)

\begin{tabular}{llll}
\hline $\begin{array}{l}\text { Effective poros- } \\
\text { ity percentage }\end{array}$ & $\begin{array}{l}\text { Qualitative } \\
\text { interpretation }\end{array}$ & Permeability values & $\begin{array}{l}\text { Qualitative } \\
\text { interpreta- } \\
\text { tion }\end{array}$ \\
\hline $0-5$ & Negligible & $5-<10$ & Poor to fair \\
$5-10$ & Poor & $15-<50$ & Moderate \\
$15-20$ & Good & $50-<250$ & Good \\
$20-25$ & Very good & $250-1000$ & Very good \\
Over 30 & Excellent & $>1000$ & Excellent \\
\hline
\end{tabular}

\section{Permeability}

From the permeability computed, it could be observed that the reservoir zones have high permeability (100 to $>1000$ $\mathrm{mD})$. The permeability was qualitatively interpreted after Abiola et al. (2018), which is indicative of good-to-excellent permeability; it means the reservoirs can transmit hydrocarbon in commercial quantity (Table 3).

\section{Empirical capillary pressure log for the reservoir zones}

The empirical capillary pressure derived was used to generate a capillary pressure log for reservoirs B and C, respectively (Fig. 6a, b). From this capillary pressure log, the actual oil-water contact, transition zone, zone fully saturated with oil and the free water zone were delineated. The capillary pressure log was interpreted after Glover (2000), Larsen et al. (2000) and Goda (Sam) et al. (2011).

\section{Well-to-seismic tie}

A graph of travel time (TWT) against depth (Z) was generated using the checkshot data of 'Stephs' field (Fig. 7a). Synthetic seismogram was generated using Butterwort wavelet
Fig. 6 a Well section for reservoir B showing empirical capillary pressure log and delineated zones. b Well section for reservoir $\mathrm{C}$ showing empirical capillary pressure log and delineated zones

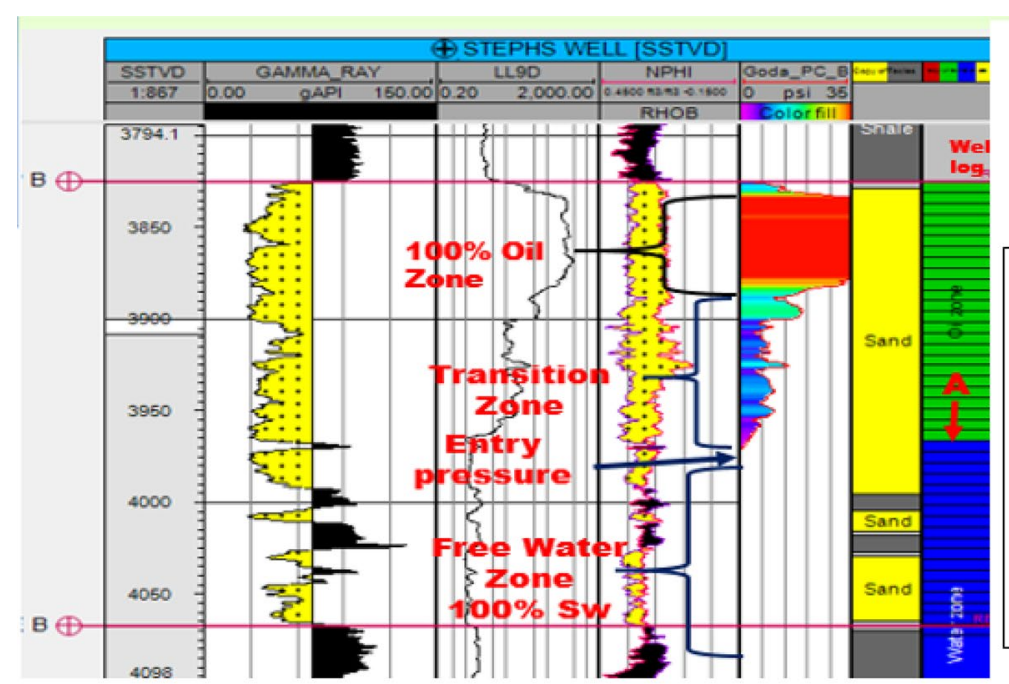

\begin{tabular}{|l|}
\hline $\mathrm{A}=\mathrm{OWC}$ \\
from Well \\
Log \\
Pressure \\
Sw= Water \\
Saturation \\
PC= \\
Capillary \\
Pressure \\
\hline
\end{tabular}

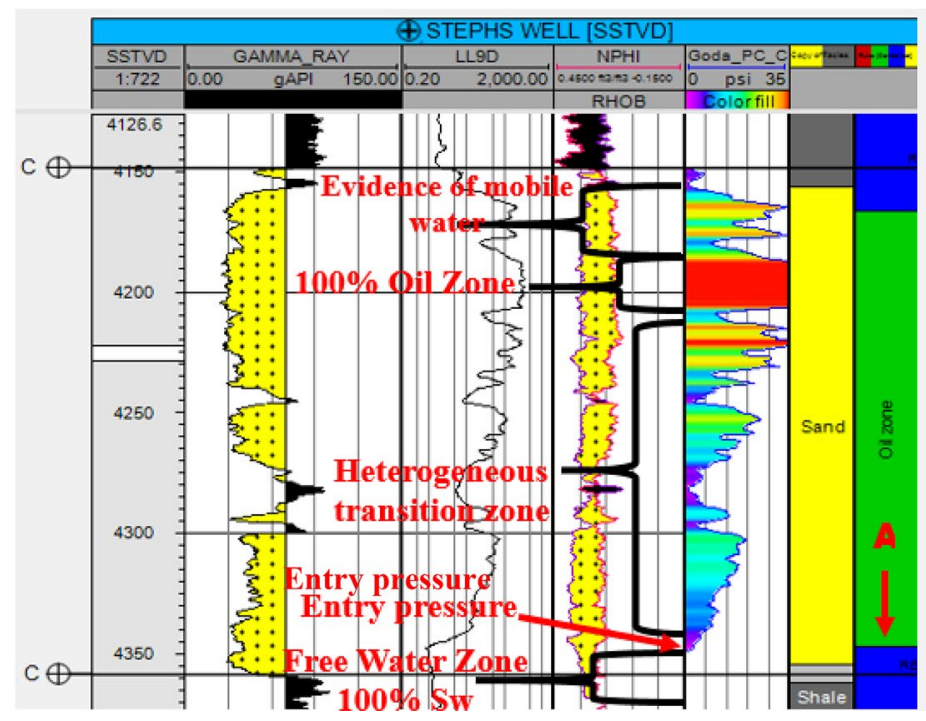

b

$\mathrm{A}^{\downarrow}=$ OWC
from Well Log
Pressure
$\mathrm{Sw}=$ Water
Saturation
$\mathrm{PC}=$ Capillary
Pressure


a

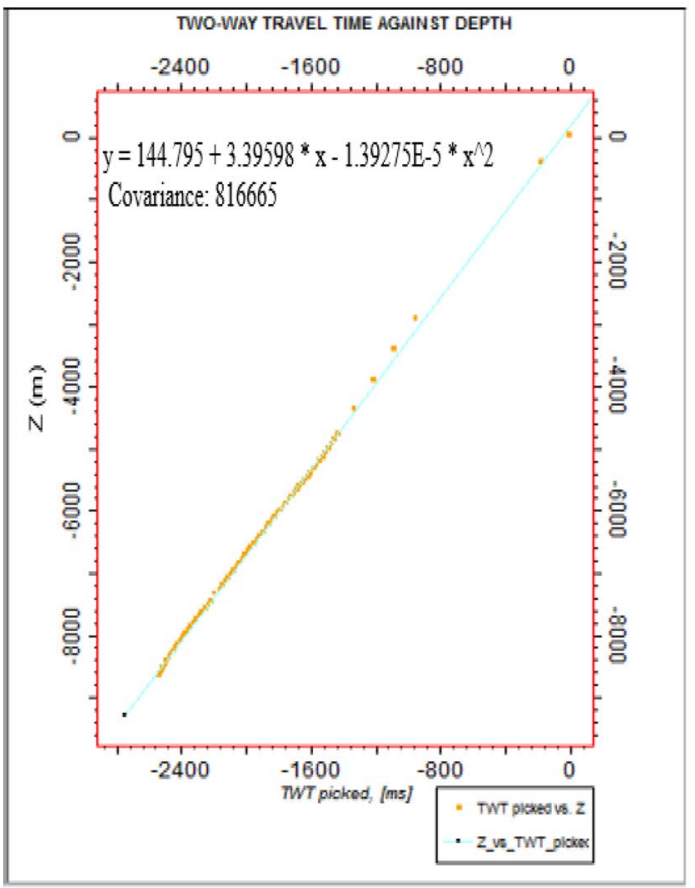

b

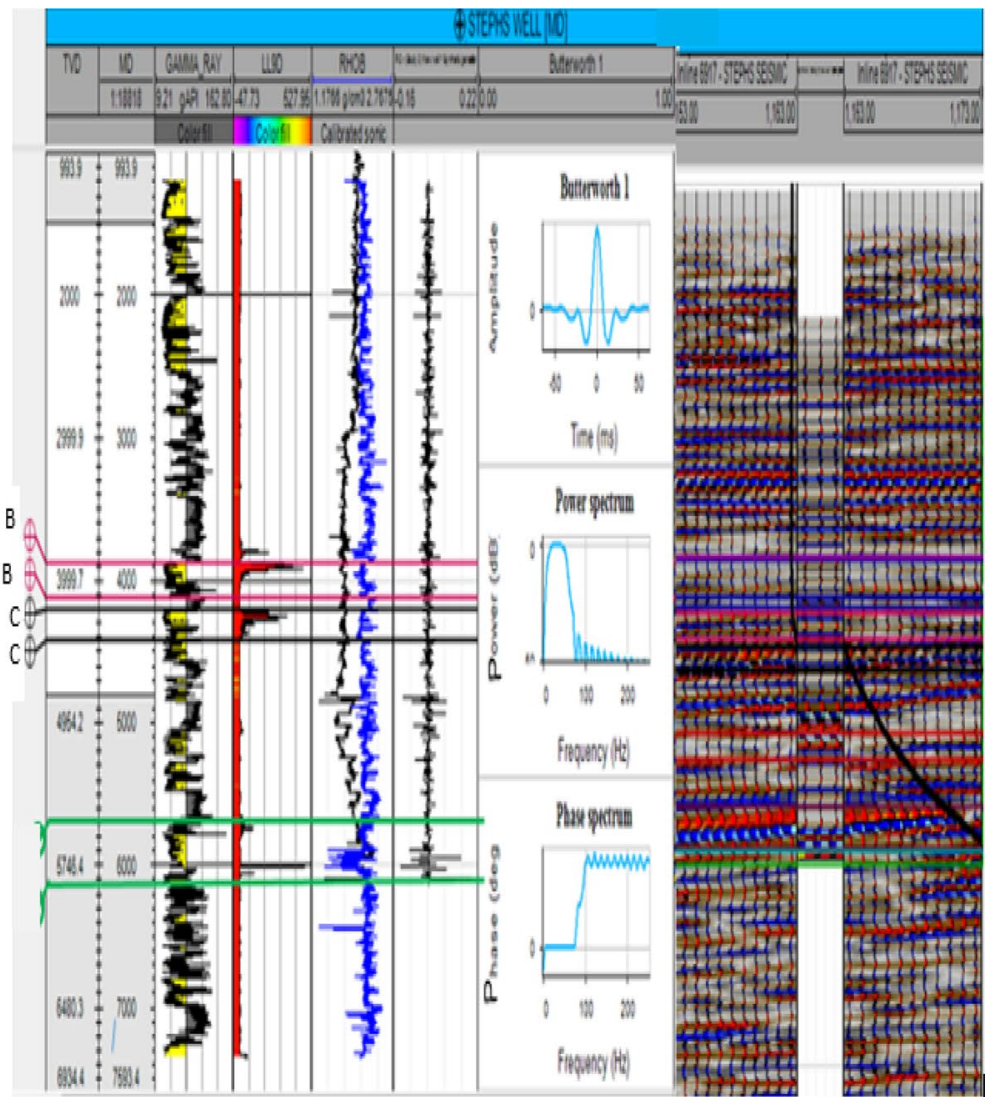

Fig. 7 a Depth $(Z)$ against two-way travel time. b Synthetic seismogram and wavelet

at zero phase sampled at an interval of $4 \mathrm{~ms}$ to establish a link between the seismic and the well (Fig. 7b).

\section{Faults and horizon mapping}

The seismic data analysis revealed the presence of major growth faults labelled Faults 1, 2, 4 and 5, and minor antithetic faults labelled Faults 3 and 6, respectively (Fig. 8). This was interpreted after Doust and Omatsola (1990), Obasuyi et al. (2019). The identified growth faults (Faults 1, 2, 4 and 5) are significant in trapping of hydrocarbon. The vertical displacements of the growth faults show that the amount of throw on both sides of the faults is small and varies from line to line (Fig. 8). Two horizons, Horizons B and $\mathrm{C}$, which represent the top of reservoirs $\mathrm{B}$ and $\mathrm{C}$, respectively, were mapped using their seismic continuities. The truncations caused by geological structures and continuities of the horizons were rigorously checked on the seismic sections (Fig. 8).

\section{Depth structure map}

Figure $9 \mathrm{a}, \mathrm{b}$ is the depth structure map of reservoirs $\mathrm{B}$ and $\mathrm{C}$ (Horizons $\mathrm{B}$ and $\mathrm{C}$ ), which reveals structural highs around the south-western and northern part of the map which is likely to serve as good prospect for hydrocarbon.

\section{Lithofacies modelling}

The lithofacies models (Fig. 10a, b) show the distribution of lithologies within the reservoir units. To define the efficiency and effectiveness of reservoir units, it is important to model property distribution within the reservoir units. In this case, the lithologies (sand and shale) within the reservoir units $\mathrm{B}$ and $\mathrm{C}$ were modelled, respectively. The volume of shale as estimated from Eq. (2) was used to model the lithologies on a fractional scale of 0 to 1 on the $3 \mathrm{D}$ grid reservoir zones. The lithofacies model is achieved by populating the estimated volume of shale property on the facies model which is interpreted to have sand and shale lithological units. Sand is the dominating lithology within these reservoir units with the characteristic of being 
Fig. 8 Interpreted Inline 5438 on seismic section showing the mapped faults and horizons

( represents the well tops)

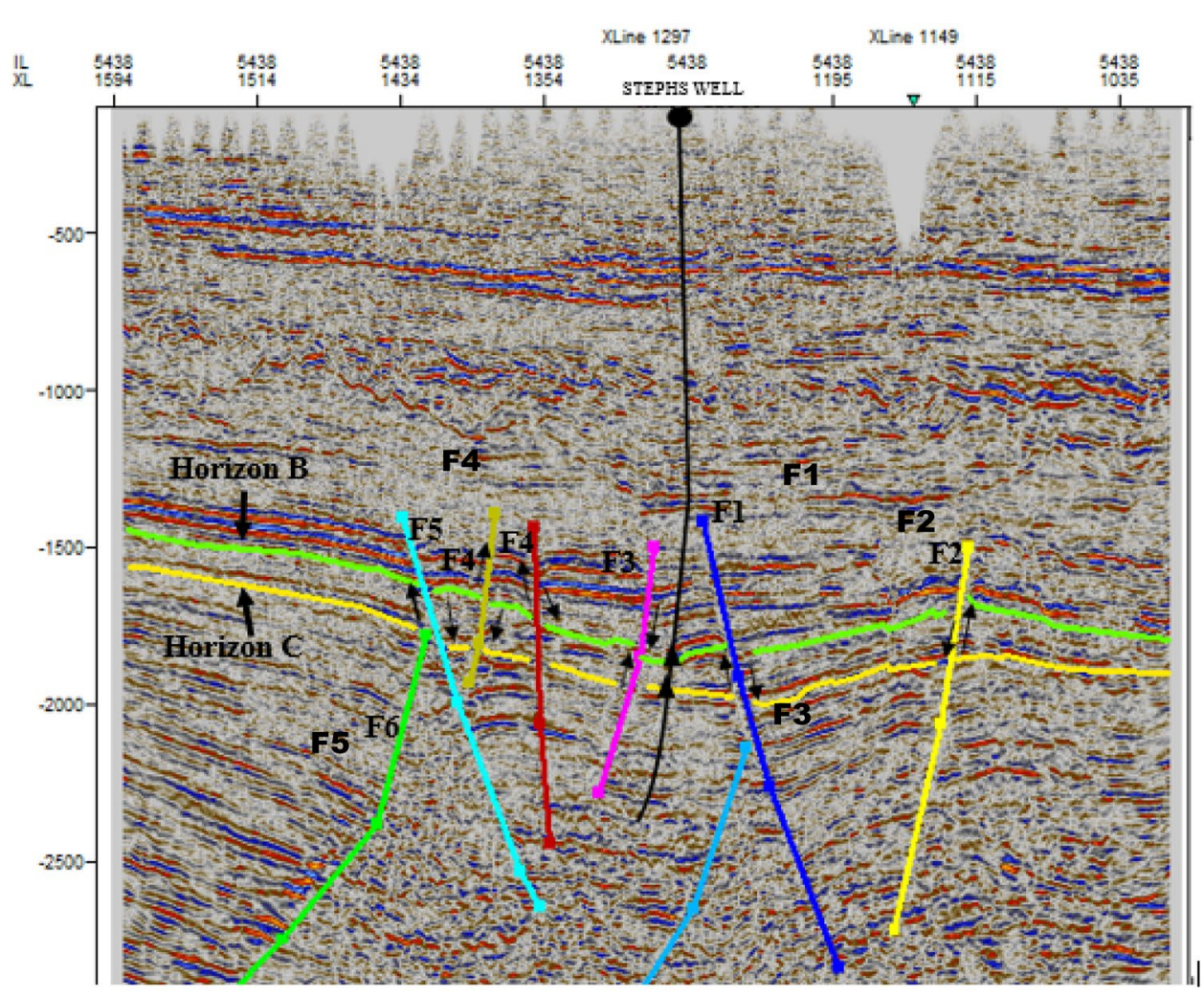

porous and permeable; as such, the sand unit can house and transmit hydrocarbon in economic quantity.

\section{Fluid modelling}

The volume of hydrocarbon estimated in fraction was modelled. From the hydrocarbon saturation model of reservoir B (Fig. 11a), it could be observed that there is a relatively high percentage (60-80\%) of hydrocarbon saturation around the drilled well region which also extends towards the northwestern and south-western parts occurring in green to yellow colour, also, the eastern portion identified as colour blue is saturated with water up to about $20-40 \%$. From the hydrocarbon saturation model of reservoir C (Fig. 11b), the hydrocarbon saturated zone occur at the northeastern region extending towards the southern portion of the model.

\section{Capillary pressure models}

The capillary pressure derived from Goda (Sam) et al.'s (2011) empirical capillary pressure model has minimum entry pressure and maximum capillary pressure to be 1.5 and 35 psi, respectively (Table 4). The empirically derived capillary pressure logs generated for each reservoir zone were used to generate capillary pressure models. The capillary pressure models (Figs. 12 and 13) describe considerably the behaviour of fluid within the reservoir units. The scale of the model ranges from 0 to 35 psi for reservoirs
B and C, respectively. For reservoir B, the capillary entry pressure is evident on the log and model of northern parts of the map (labelled C), which ranges between 1.5 and 6.0 psi (Fig. 12a, b). The transition zone is evident on the capillary pressure log and model as the colour progresses from deep blue, through green to light blue with capillary pressure values ranging from 6 to 18 psi (labelled D). The red colour with values ranging from 18 to 35 psi exists as the zone with high capillary pressure which is indicative of the zones fully saturated with hydrocarbon (oil); this is evident on the eastern part of the model and region labelled ' $\mathrm{E}$ ' on the capillary pressure log and model.

The capillary pressure reservoir $\mathrm{C}$ was upscaled, and the sequential Gaussian simulation was used to generate the capillary pressure model. The capillary entry pressure (Table 4) is evident on the model at the north-eastern part of the model with values ranging between 3.45 and 7 psi (region on the $P_{\mathrm{c}} \log$ and model labelled $\mathrm{C}$ and C'). The transition zone is evident as the colour progresses from deep blue to light blue at the region labelled D and D' on the well section and model at north-western region with capillary pressure values ranging between 8 and 17.5 psi. The red colour region exists as the zone with high capillary pressure (17.5-35 psi) is indicative of the zones fully saturated with hydrocarbon (observed at the north-western and southern parts of the model) (Fig. 13a, b). From the model, it is evident that mobile water still exists within the reservoir zone.

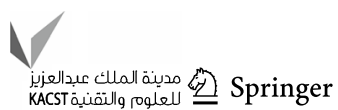


Fig. 9 a Depth structure map of horizon B. b Depth structure map of horizon $\mathrm{C}$ a

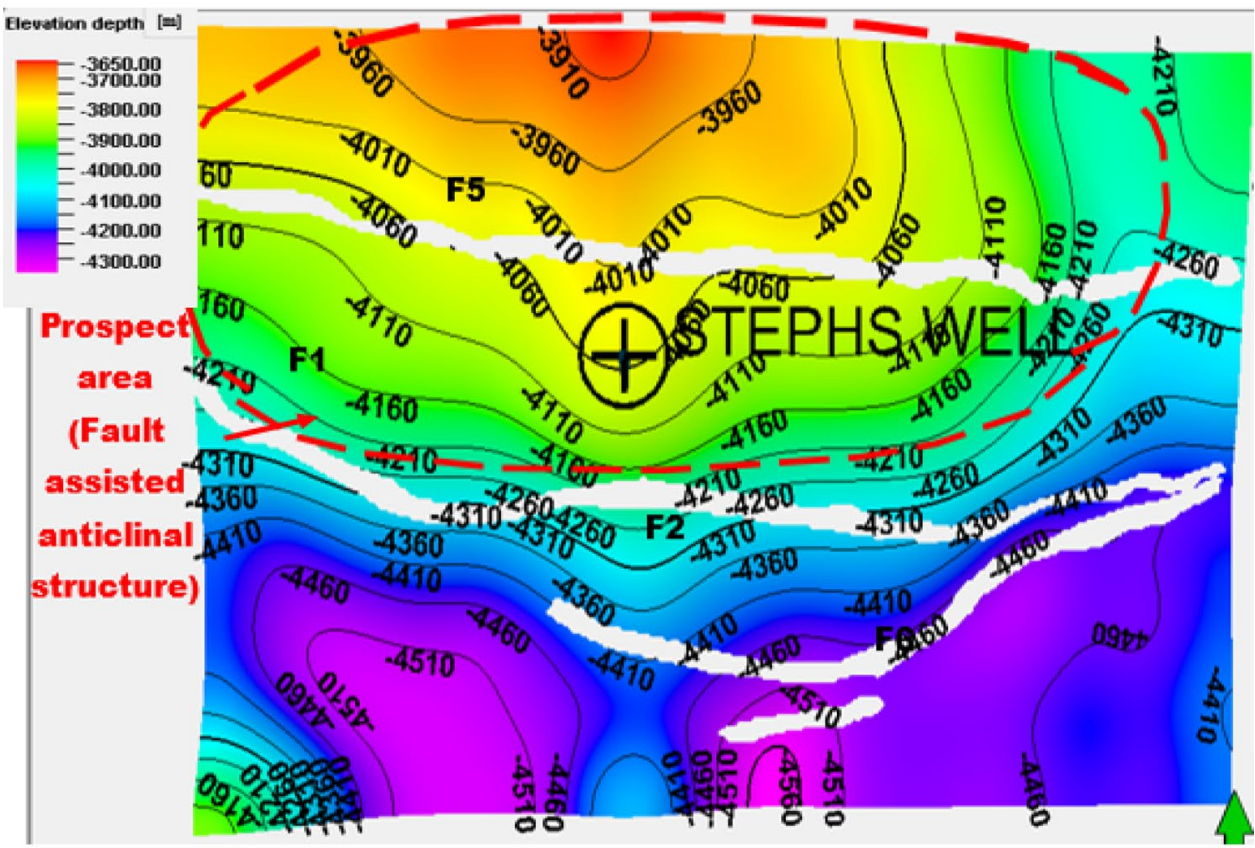

b

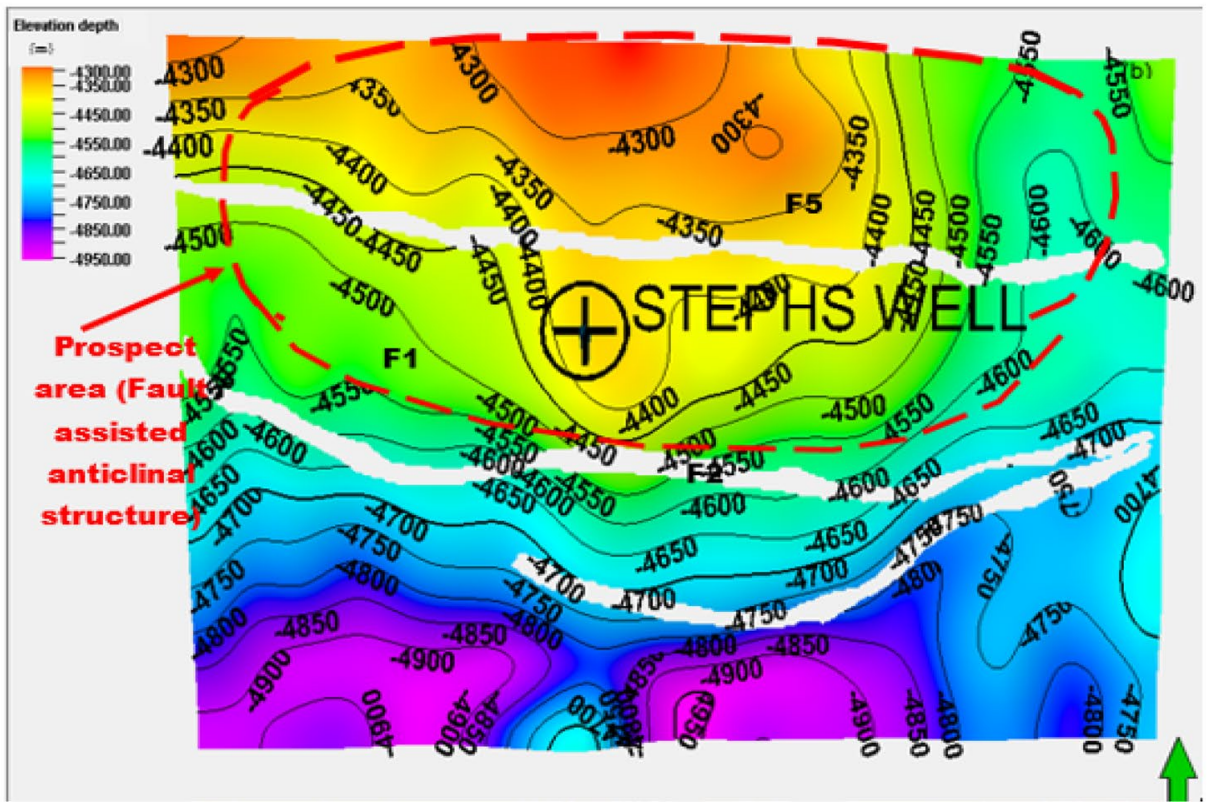

The southern flank labelled $\mathrm{E}$ on the capillary pressure $\log$ (well section) and on the model is characterized by high capillary pressure, which indicates the zone in which economic hydrocarbon can be extracted. The zone labelled $\mathrm{A}$ is the free water level; $\mathrm{B}$ is the oil water contact for reservoirs B and C. From reservoir C, it is observed that there is an evidence of water entering the reservoir from the caprock which could be an evidence of leaking seal. The occurrence of thin layers of shale within the reservoirs is an indication of complex reservoir architecture (heterogeneous zones). One advantage of modelling capillary pressure is identifying reservoir zones in three dimensions in which water is mobile; this cannot be delineated by merely studying the capillary pressure curve (a plot of capillary pressure against water saturation). The zones identified on the capillary pressure are also identified on the capillary pressure log generated. 
Fig. 10 a Lithofacies model for reservoir B. b Lithofacies model for reservoir $\mathrm{C}$

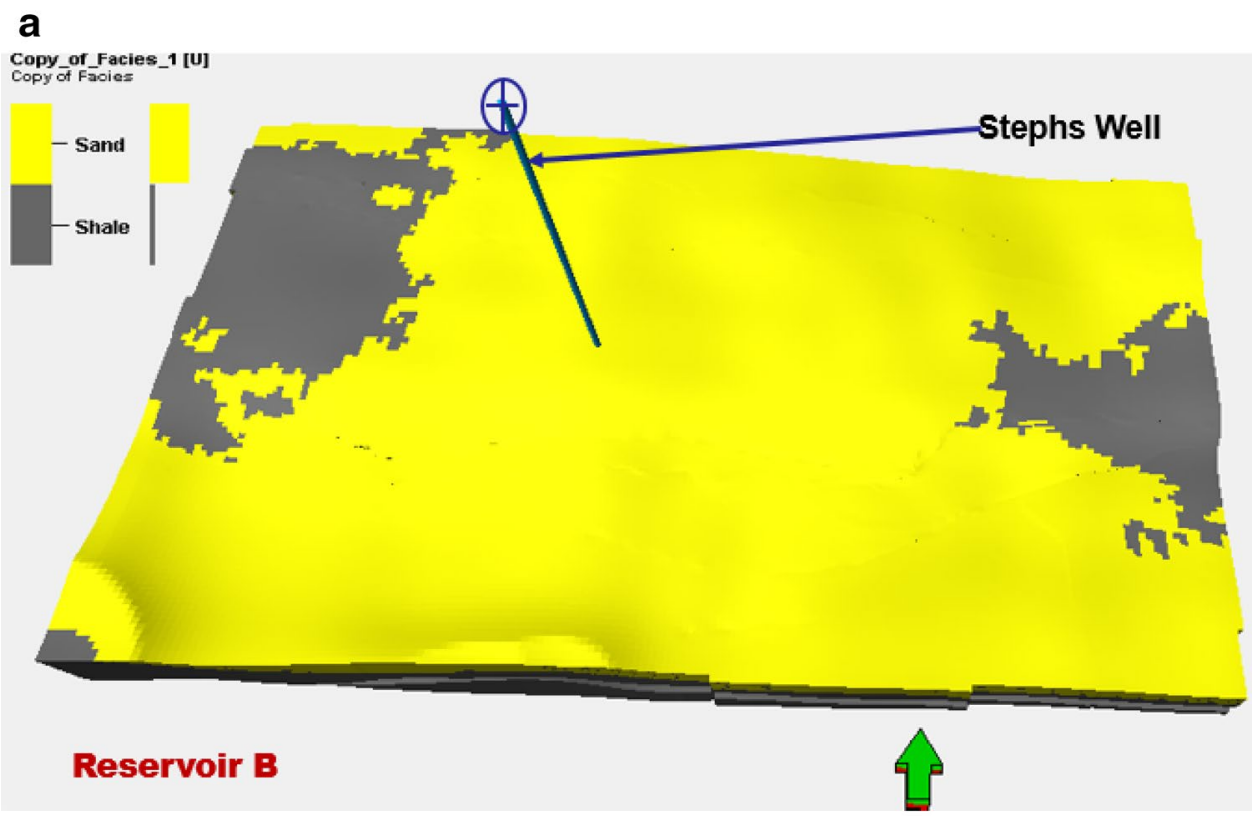

b

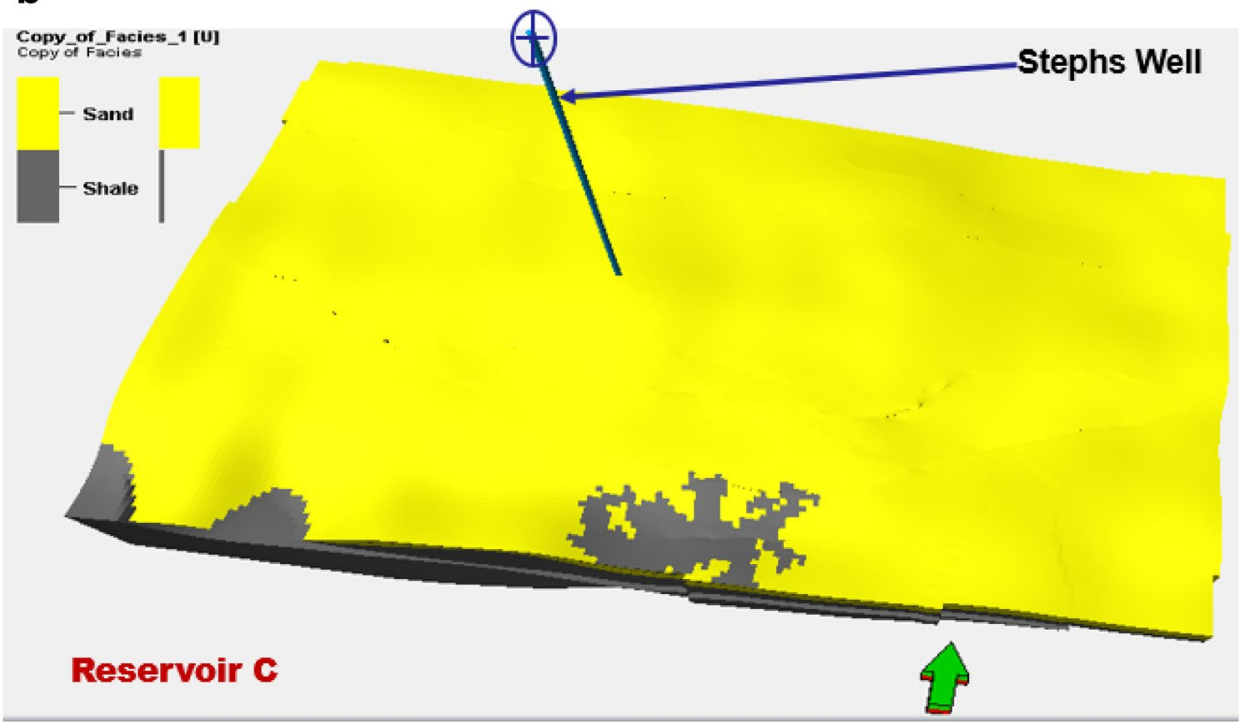

\section{Capillary pressure curves}

The plot of capillary pressure against water saturation for reservoirs B and C is presented in Fig. 14a, b. The capillary pressure curves show the meeting point of the fluid (where two fluids of different phases that are immiscible meet, capillary pressure is zero Pascoal 2015) below which is the FWL; there is an entry pressure as hydrocarbon tries to overcome the displacement pressure. The transition zone indicating the zone of interaction between the two-phase fluids (water and hydrocarbon) is evident at the curved region with the blue colour bar and the zone fully saturated with hydrocarbon (represented with a red colour bar). The capillary pressure curves are steep, which is an indication that the grains within the reservoirs are well sorted.

\section{Volumetric analysis}

In estimating the volume of oil in place, two cases were considered. The first case was estimating the volume of oil in place without taking transition zone into consideration (volume of oil 1), and the second case was estimating the oil in place with taking transition zone into consideration (volume of oil 2) (Table 5). The illustration below gives a clear description of the ranges between the volumes of oil obtained: volume of oil 1 (oil + mobile water in transition 
Fig. 11 a Hydrocarbon saturation model for reservoir $\mathbf{B}$. $\mathbf{b}$ Hydrocarbon saturation model for reservoir $\mathrm{C}$ a

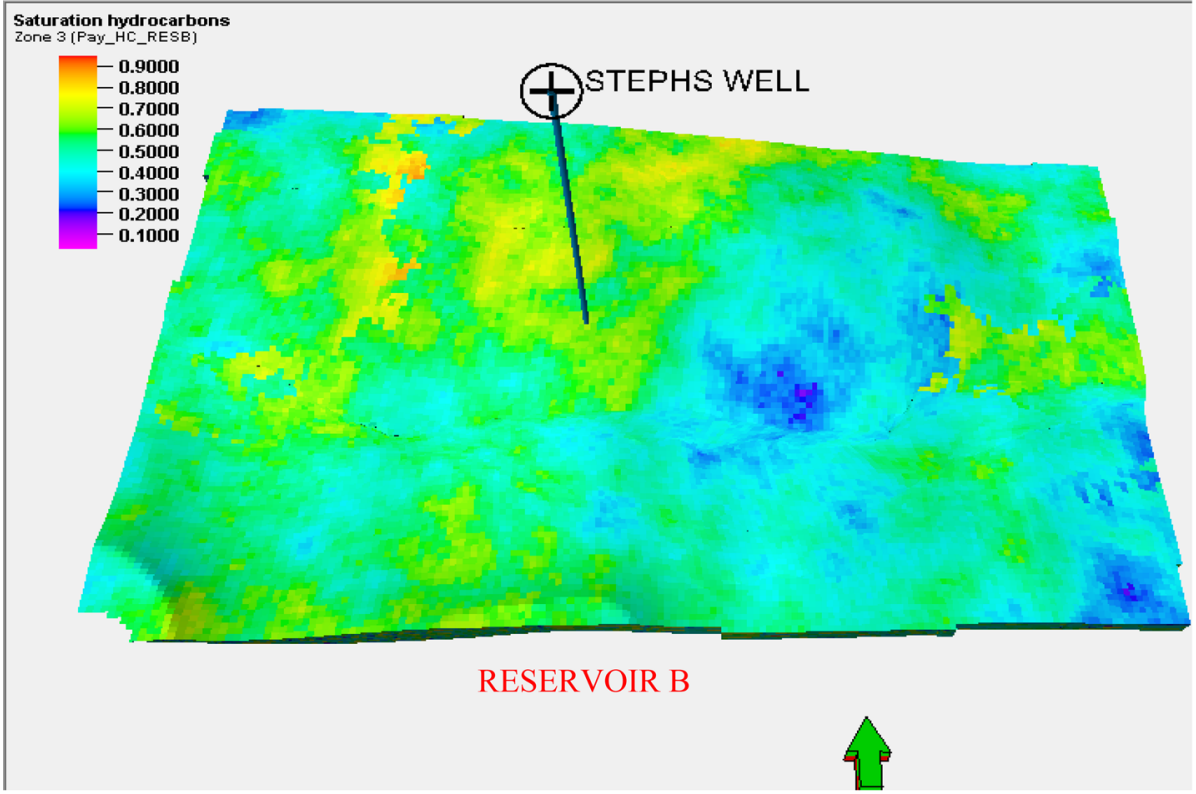

b

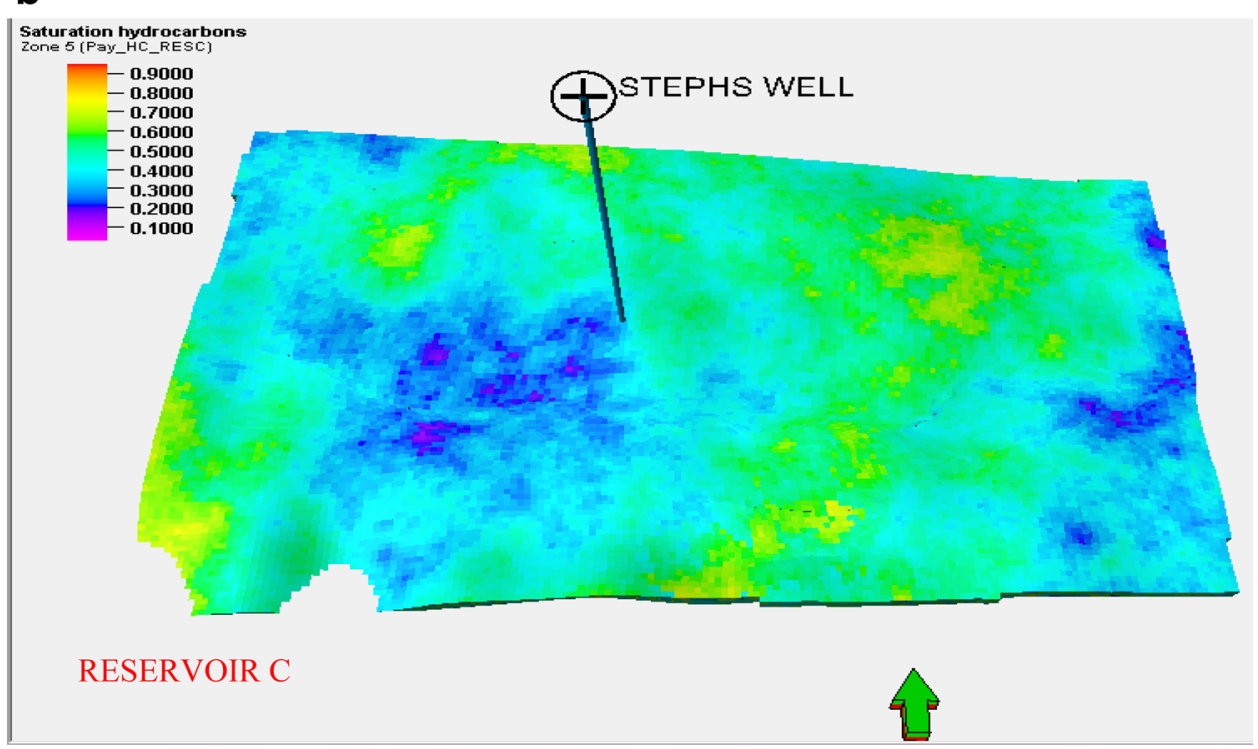

zones) > volume of oil 2 (volume of oil-mobile water in transition zones).

Table 4 Oil-water contact depth and empirical capillary pressure values

\begin{tabular}{llll}
\hline Name of the reservoir & $\begin{array}{l}\text { Oil-water } \\
\text { contact } \\
(\mathrm{m})\end{array}$ & $\begin{array}{l}\text { Capillary entry } \\
\text { pressure (psi) }\end{array}$ & $\begin{array}{l}\text { Maximum cap- } \\
\text { illary pressure } \\
(\mathrm{psi})\end{array}$ \\
\hline Reservoir B & 3963.32 & 1.50 & 35.00 \\
Reservoir C & 4347.29 & 3.45 & 35.00 \\
\hline
\end{tabular}

For reservoir B, the difference between the volume of oil $1\left(273 \times 10^{6} \mathrm{mmbbls}\right)$ and volume of oil $2\left(242 \times 10^{6} \mathrm{mmb}-\right.$ bls) is $31 \times 10^{6}$ mbbls. For reservoir $\mathrm{C}$, the difference between the volume of oil $1\left(406 \times 10^{6} \mathrm{mmbbls}\right)$ and volume of oil $2\left(256 \times 10^{6} \mathrm{mmbbls}\right)$ is $150 \times 10^{6} \mathrm{mmbbls}$. The difference between these estimated volumes further confirms the presence of mobile water in the reservoirs. Thus, the volume of RHC estimated without taking transition zone into consideration is higher than the estimates obtained while transition analysis was performed. 
Fig. 12 a Well section with capillary pressure log for reservoir B. A is FWL, B is OWC, $\mathrm{C}$ is entry pressure, $\mathrm{D}$ is transition zone and $\mathrm{E}$ is the zone fully saturated with hydrocarbon. b Capillary pressure model for reservoir $\mathrm{B}$ (A is FWL, B is OWC, $\mathrm{C}$ is low- $\mathrm{P}_{\mathrm{c}}$ zone, $\mathrm{D}$ is transition zone and $\mathrm{E}$ is the zone fully saturated with hydrocarbon)

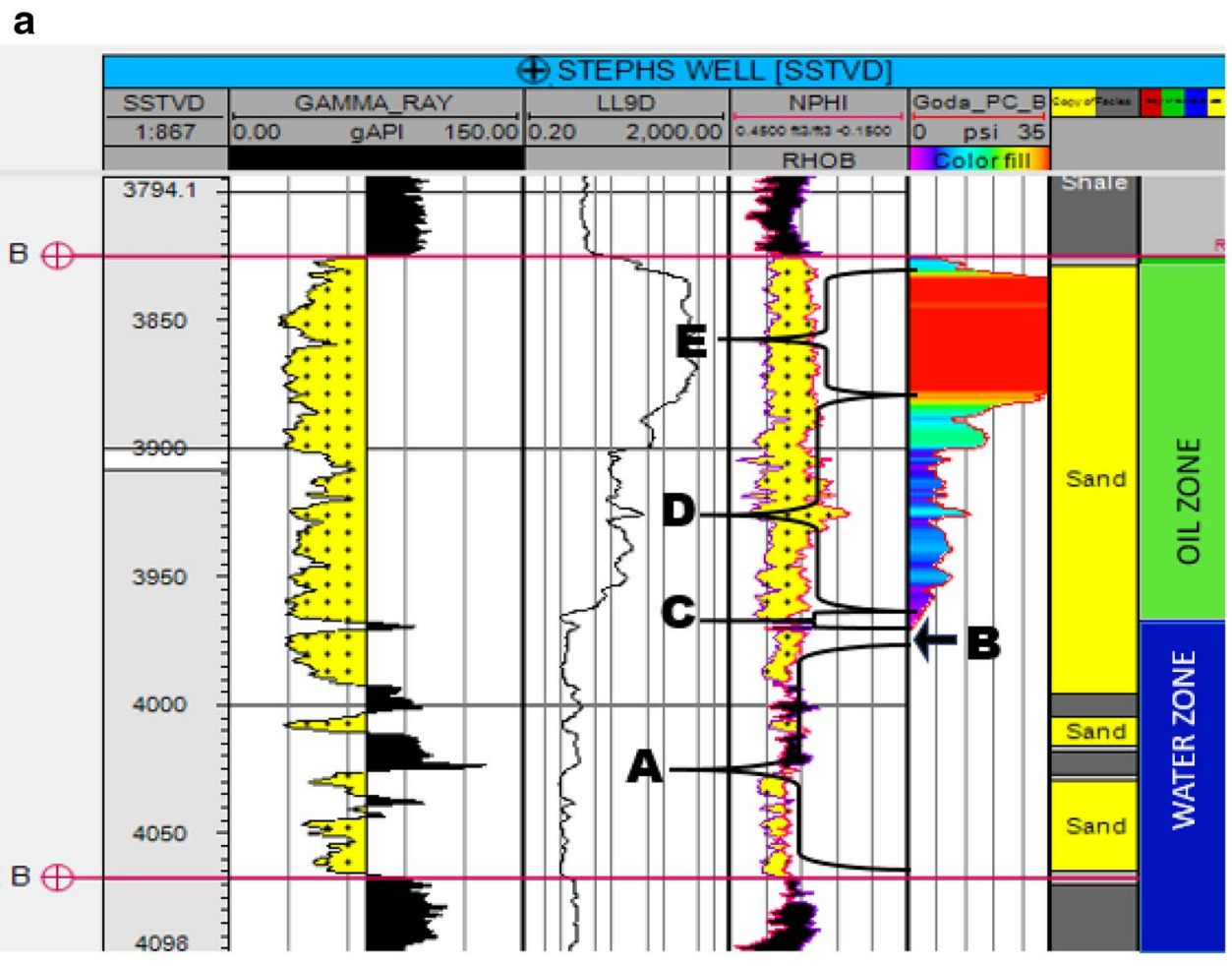

b

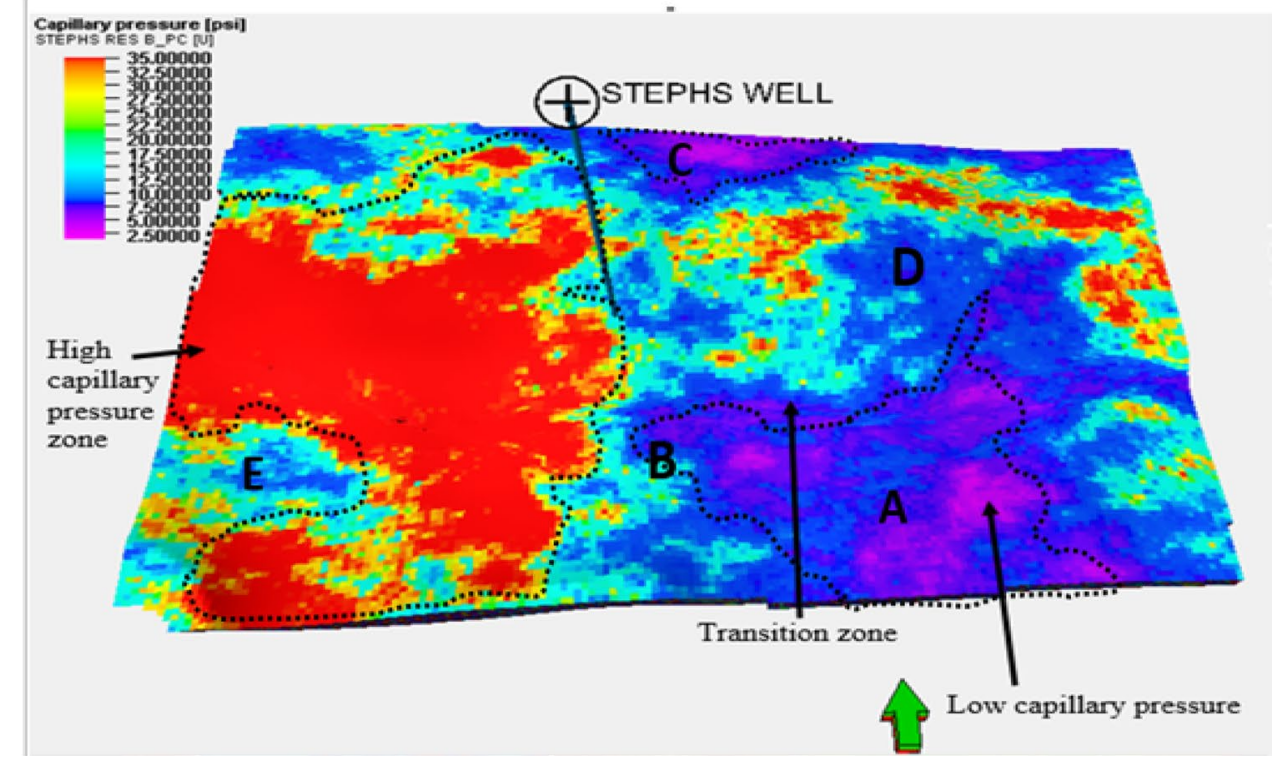

\section{Conclusions}

Two reservoirs (RES B and C) were delineated with thickness values of 209.08 and $194.14 \mathrm{~m}$. Computations of the petrophysical parameters of the reservoirs show that the area is highly porous and permeable. The effective porosity within the reservoirs ranges from 10 to $30 \%$, and the permeability ranges from 100 to $1000 \mathrm{mD}$, which is an important characteristic of good hydrocarbon bearing zone. The modelling of these parameters further buttresses this point as it is evident on the models generated.

Six faults were mapped on the seismic volume as Faults 1, 2, 3, 4, 5 and 6. Faults 1, 4 and 5 are the major growth faults. Two horizons were mapped using the top of each reservoir to generate time and depth structural maps. The time and depth structural maps produced for the horizon mapped show a fault-assisted anticlinal structure.

The capillary pressure model generated was useful in describing the mobility of water within the reservoirs by 
Fig. 13 a Well section with capillary pressure log for reservoir C. A is FWL, B is OWC, C \& $\mathrm{C}^{\prime}$ is entry pressure, D \& D' is transition zone, $\mathrm{E}$ is the zone fully saturated with hydrocarbon. b Capillary pressure model for reservoir $\mathrm{C}$ ( $\mathrm{A}$ is FWL, B is OWC, $\mathrm{C}$ is low- $\mathrm{P}_{\mathrm{c}}$ zone, $\mathrm{D}$ is transition zone and $\mathrm{E}$ is the zone fully saturated with hydrocarbon)
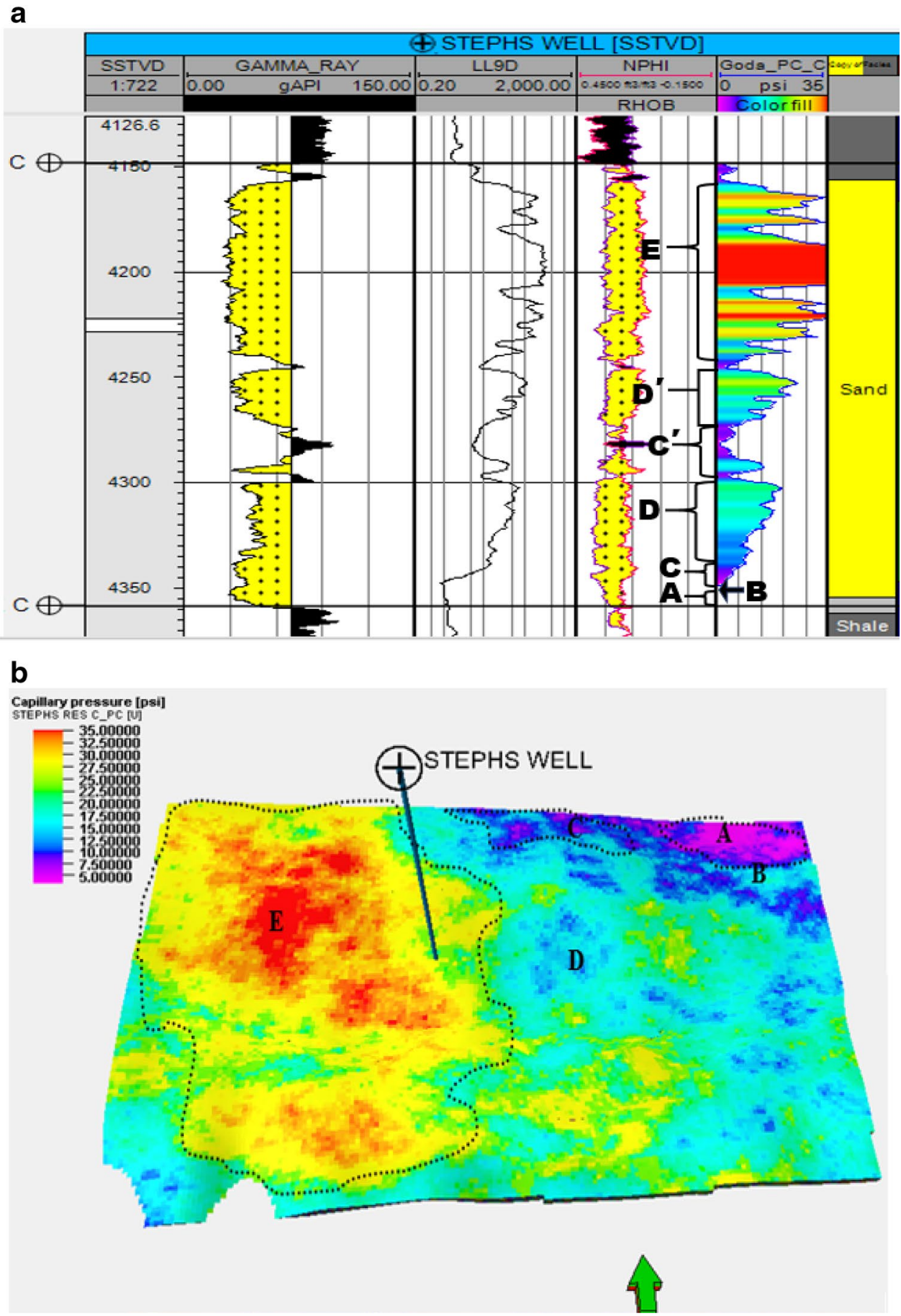

identifying the zones with low capillary pressure (entry pressure), the zone with water and hydrocarbon (transition zones) and the zone fully saturated with hydrocarbon.

The volume of oil estimated without taking transition zone into consideration was found to be higher at $273 \times 10^{6}$ and $406 \times 10^{6} \mathrm{mmbbls}$ than the values of estimated hydrocarbon while taking transition zone into account at $242 \times 10^{6}$ and $256 \times 10^{6}$ for reservoirs B and C, respectively. This indicated the presence of mobile water to be $31 \times 10^{6}$ and $150 \times 10^{6} \mathrm{mmbls}$ for reservoirs $\mathrm{B}$ and $\mathrm{C}$. These findings have shown that recoverable hydrocarbon (RHC) for some reservoirs is overestimated; hence, transition zone analysis has to be performed while performing sensitivity analysis for enhanced hydrocarbon recovery. 

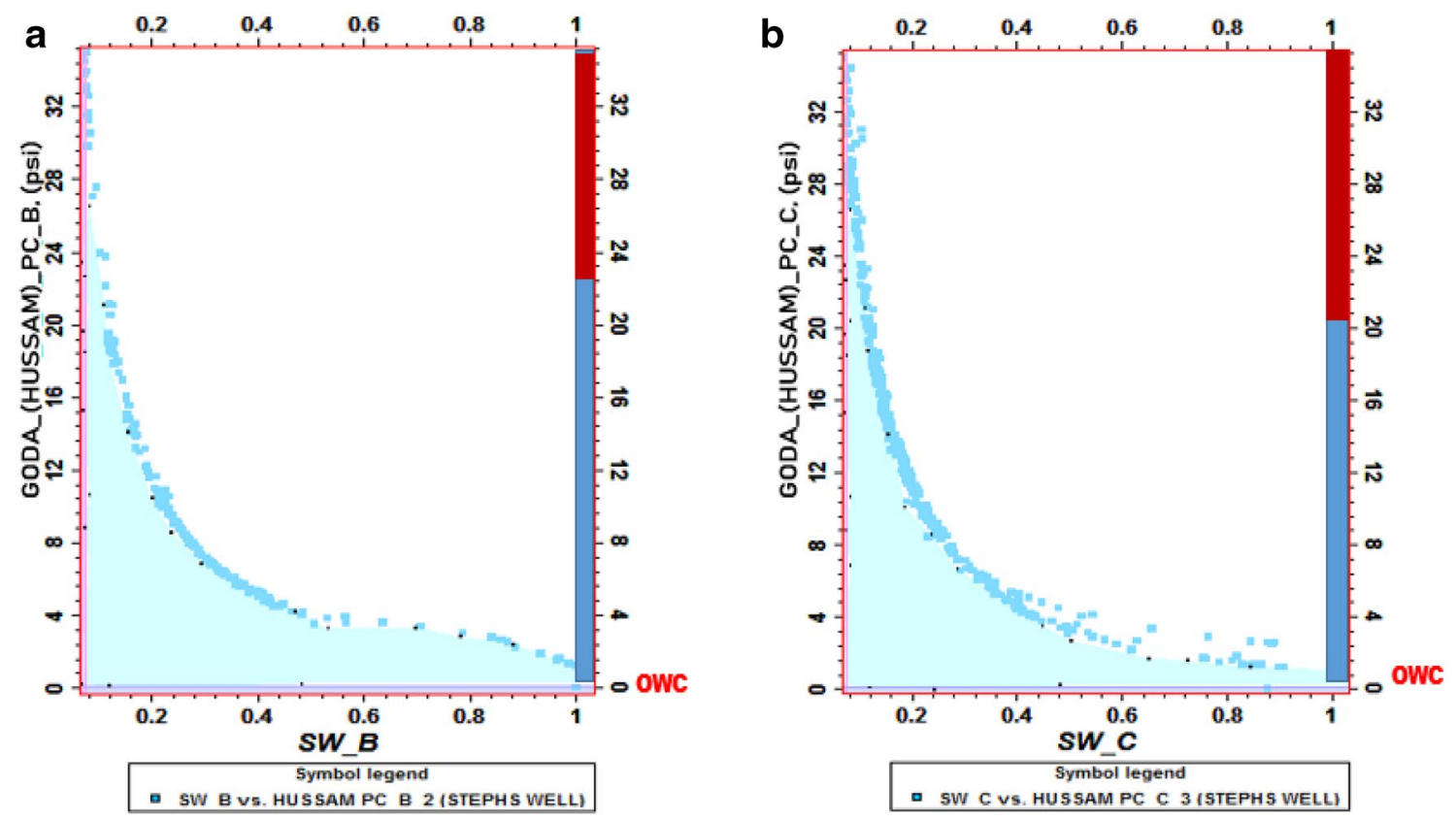

Fig. 14 Capillary pressure curves for reservoirs B and C

Table 5 Volume of oil without transition zone analysis and with transition zone analysis

\begin{tabular}{llll}
\hline $\begin{array}{l}\text { Name of the } \\
\text { reservoir }\end{array}$ & $\begin{array}{l}\text { Volume of } \\
\text { oil 1 (without } \\
\text { transition } \\
\text { zone analysis) } \\
\left(* 10^{6} \text { mmbbls }\right)\end{array}$ & $\begin{array}{l}\text { Volume of oil 2 } \\
\text { zone analysis) } \\
\left(* 10^{6} \text { mmbbls }\right)\end{array}$ & $\begin{array}{l}\text { Volume of } \\
\text { mobile water } \\
\text { within reservoirs } \\
\left(* 10^{6} \text { mmbbls }\right)\end{array}$ \\
\hline Reservoir B & 273 & 242 & 31 \\
Reservoir C & 406 & 256 & 150 \\
\hline
\end{tabular}

Open Access This article is licensed under a Creative Commons Attribution 4.0 International License, which permits use, sharing, adaptation, distribution and reproduction in any medium or format, as long as you give appropriate credit to the original author(s) and the source, provide a link to the Creative Commons licence, and indicate if changes were made. The images or other third party material in this article are included in the article's Creative Commons licence, unless indicated otherwise in a credit line to the material. If material is not included in the article's Creative Commons licence and your intended use is not permitted by statutory regulation or exceeds the permitted use, you will need to obtain permission directly from the copyright holder. To view a copy of this licence, visit http://creativecommons.org/licenses/by/4.0/.

\section{References}

Abiola O, Olowokere MT, Ojo JS (2018) Sequence stratigraphy and depositional sequence interpretation, a case study of "george" Field Offshore Niger Delta, Nigeria. J Pet Res 3:25-32

Christiansen RL (2001) Two-phase flow through porous media: theory, art and reality of relative permeability and capillary pressure. Petroleum Engineering Department, Colorado School of Mines, Colorado

Doust H, Omatsola E (1990) Niger-Delta. In: Edwards JD, Santogrossi PA (eds) Divergent/passive margins basins: AAPG Memoir, vol 48, pp 201-238

Glover P (2000) Saturation and capillary pressure. Unpublished Lecture Note, chap 4, pp 1-23

Goda (Sam) H, PetroPerth Consulting SPE, Behrenbruch P (2011) A Universal formulation for the prediction of capillary pressure. University of Adelaide. SPE 147078. Copyright 2011, Society of Petroleum Engineer, pp 1-22

Hartmann DJ, Beaumont EA (1999) Predicting reservoir system quality and performance. In: Beaumont EA, Foster NH (ed) Treatise of petroleum geology/handbook of petroleum geology: exploring for oil and gas traps, Ch 9, pp 1-154

Jamiolahmady M, Sohrabi M, Tafat M (2007) Estimation of saturation height function using capillary pressure by different approaches. In: EUROPEC/EAGE conference and exhibition, London. SPE 107142, pp 8-12

Johan OH, Svein MS (2005) Modelling of three-phase capillary pressure for mixed-wet reservoirs. Stavanger University College Report. pp 10

Kumar R, Cherukupalli PK, Lohar BL (2002) Saturation modelling in a multilayered carbonate reservoir using log-derived saturation height function. In: SPE/DOE improved oil recovery symposium, Tulsa. SPE 75213, pp 1-37

Larsen JA, Trond T, Geir Haaskjold Norsk Hydro Research Centre (2000) Capillary transition zones from a core analysis perspective. Norsk Hydro Research Centre Publication, Bergen, Norway

Leverett MC (1941) Capillary behavior in porous solid. Society of Petroleum Engineers Liberty Field, Alaska. All Rights Reserved Logging Symposium, (c) CGG, pp 13-16

Obasuyi FO, Abiola O, Egbokhare JO, Ifanegan AS, Ekere IJ (2019) 3D seismic and structural analysis of Middle Agbada reservoir sand, Offshore Niger Delta, Nigeria. J Geogr Environ Earth Sci Int 20(3):1-12. https://doi.org/10.9734/jgeesi/2019/v20i330108 
Okoli EC, Ujanbi O (2007) Estimation of height of oil-water contacts above free water using capillary pressure method for effective classification of reservoirs in the Niger Delta. Niger J Phys 19(2):303

Pascoal DT (2015) Saturations calculations using saturation-height modeling on well Mariana, Offshore Congo Basin, NTNU, petroleum system: Niger Delta Province, Nigeria Cameroon, and Equatorial Guinea, Africa Guinea, Africa. United States Geological Survey, Open- File Report 99- 50- H, p 65

Renzo A, Carlos T, Abdolhamid H, Kamy S (2010) Estimation of capillary pressure and relative permeability from formation-tester measurements using design of experiment and data-weighing inversion. J Pet Sci Eng 75:19-32

Sarwaruddin MA, Skauge A, Torsaeter O (2001) Fluid distribution in transition zones (using a new initial-residual saturation correlation). Norwegian University of Science \& Technology, Norsk Hydro Publication, Trondheim, pp 1-8

Skelt C, Harrison B (1995) An integrated approach to saturation height analysis. In: 36th annual logging symposium transactions: society of professional well log analysts, Paper NNN, pp 5-17

Sonibare O, Alimi H, Jarvie D, Ehinola OA (2008) Origin and occurrence of crude oil in the Niger delta. Niger J Pet Sci Eng 61(2-4):99-107
Tixier MP (1949) Evaluation of permeability from electric log resistivity gradient. Earth Sci J 2:113

Vavra CL, Kaldi JG, Sneider RM (1992) Geological applications of capillary pressure: a review. AAPG Bull 76:840-850

Wiltgen NA, Calvez JL, Owen K (2003) Methods of saturation modelling using capillary pressure averaging and pseudos. SPWLA Paper W presented at the Annual Logging Symposium, 22-25 June

Wu T (2004) Permeability prediction and drainage capillary pressure simulation in sandstone reservoirs. PhD Dissertation, University of Texas A \& M, Texas

Zhao G, Zhu J, Guan L (2008) Method of applying capillary pressure data to calculate initial oil saturation. J China Univ Pet 22(4):38-41

Publisher's Note Springer Nature remains neutral with regard to jurisdictional claims in published maps and institutional affiliations. 